\title{
Regional Scale Alteration Mineral Mapping using ASTER Imagery in Sparsely Vegetated Terrain: a case study from Eastern Part of South Purulia Shear Zone, India
}

\author{
Pankajini Mahanta*, Sabyasachi Maiti \\ Department of Geology and Geophysics, Indian Institute of Technology, Kharagpur, West Medinipur, West Bengal,
} India-721302

\begin{abstract}
The use and recognition of remote sensing technique for geological application has been increased manifold in the last two decades. Although greater achievements were made in public availability of data, sensor resolution such as revisiting time, spatial resolution and temporal resolution, mineral exploration in unexplored vegetated region is still remain challenging. The vegetation present in the terrain hiders the signature of the underlying geological material partially. Therefore, locating the potential zone for hydrothermal deposits becomes more difficult in such domain. The current work documented mineral mapping on a sparsely vegetated terrain, i.e., eastern part of South Purulia Shear Zone, India using ASTER imagery. It provides a comparative study of Band ratio and Directed Principal Component Analysis for alteration mineral mapping. The remotely derived results have been correlated and validated with field evidences and geomorphic features identified from the high resolution Geoeye imagery. Alteration zones are observed to developed parallel to the shear zone as small-scale discrete pockets. The DPC result has been interpreted in two different ways shows accuracy of $79.31 \%$ for $14^{\text {th }}$ standard deviation classification scheme, and $77.01 \%$ for band combination with thresholding and linear stretching techniques. Hydrothermal alteration zones identified from the study seeks further details study on alteration and mineralization.
\end{abstract}

Keywords: ASTER; Band ratio; Directed Principal Component Analysis; Alteration mapping; vegetated terrain

\section{INTRODUCTION}

Regional scale mapping is important in the reconnaissance stage of mineral exploration for narrowing down the target area of ore prospecting. With advancement, remote sensing methods are now capable to identify key pathfinder minerals, quantify alteration intensity and mapping chemical variations that are invisible to even the most experienced exploration geologists $(1,5,7,8,15,16,25,26,43)$. Remote sensing is the quick accessible, easy interpretable and cheapest tool to narrow down the target area in the very initial stage of exploration, specifically for the hydrothermal deposits $(22,24,31$, $32,38)$. Alteration products are key pathfinders for hydrothermal mineral deposits. Thus, their identification plays crucial role in regional scale mineral mapping. Although the scale of actual ore occurrences is in small scale for many hydrothermal ore deposits, the geological proxies like alteration, vegetation stress, and fractures occur in larger scale. Demarcation of large-scale hydrothermal alteration halos using remote sensing techniques is quite straight forward in absence of vegetation as documented from many parts of the world $(22,24,31,32,38)$. Multi-spectral/ hyperspectral satellite imageries are the first choice of many researchers for alteration mineral mapping with different digital image processing (DIP) techniques viz. band ratio, Principal Component Analysis (PCA), Minimum Noise Fraction (MNF), Spectral Angle Mapper (SAM), Spectral Information Divergence (SID), Constrained Energy Minimization (CEM), Linear Spectral Unmixing (LSU), and Mixture-Tuned Matched-Filtering (MTMF). Each technique has its own advantages and limitations. However, their integration can reveal improved information for exploration. Band ratio is useful for reducing the effect of topography for enhancing subtle differences in the spectral reflectance and provides useful information regarding mineral identification, however it is affected by vegetation resulting false positive anomaly $(35,40)$. Likewise, PCA effectively reduces the data dimensionality and transforms the highly correlated reflectance bands to uncorrelated Principal Components (PCs); but the PCs do not necessarily carry important geological information. Whereas their combined use referred as Directed Principal Component Analysis can help reduce the effect of vegetation while providing partial information on underlying material $(34,23)$. All these commonly used mineral mapping techniques have successfully applied in the desert or arid region with extensive outcrop in absence of vegetation. However, dense vegetation cover, persistence cloud cover and unavailability of the data, inadequate bedrock exposure, are the challenges for regional scale mineral mapping using the remote sensing data in tropical regions in comparison to arid and semiarid regions $(33,34,45)$. Only a few attempts have been made for mineral mapping in highly vegetated 


\section{DOI: $10.17148 /$ IARJSET.2021.8899}

areas like tropical and subtropical region and, DPCA was employed by separating vegetation signature from rocks and soil $(8,17,33,34,42)$. Close spatial association of gossanized zone and hydrothermal alteration with mineralization present in the study area. Considering the prominent alteration types of the study area which includes argillisation and ferruginisation as two most dominant alteration types among all, we have considered major two types of mineral assemblages, such as, low-temperature hydrothermal type (alunite, kaolinite, illite, smectite, chlorite, white mica, pyrophyllite, carbonates and quartz) and gossan type (hematite, goethite, jarosite, limonite). The aim of the study is to a) remotely map the regional distribution of alteration minerals using band ratio and DPCA techniques with ASTER data for eastern part of South Purulia Shear Zone (SPSZ), b) validating the results with field observation and c) mark the plausible hydrothermal mineralized zone for detail exploration.

\section{STUDY AREA}

The eastern end of SPSZ is considered in the current study for hydrothermal alteration mapping using band ratio and DPCA techniques. The SPSZ is marked by a $120 \mathrm{~km}$ long and 4-5 km wide corridor of highly deformed and altered rock assemblages, bounded in-between Chhottanagpur Granite Gneissic Complex (CGGC) and North Singhbhum Mobile Belt (NSMB) (2). The major rock types are granitoids, gneisses, quartzite, quartz breccia, migmatites, schist, tuffaceous phyllite, pyroxenite, quartz-magnetite-apatite, tourmalinite, hornblende schist, epidiorite and amphibolites $(3,6,10,27)$ (Fig. 1). The rock of SPSZ belongs to either NSMB or CGGC. Main constituents of NSMB are deformed metapelites, meta-igneous and meta- sedimentary rocks of Proterozoic age (1.0-2.4 Ga) $(4,39)$. Previous researchers $(3$, 9) have reported the minor occurrences of apatite magnetite carbonatite and alkali pyroxenite rock association along the SPSZ. The occurrence of carbonatite has been reported from Mednitanr and Kutni areas based on drill-core samples (3). Lensoidal occurrence of apatite-magnetite of various dimensions have also reported along the SPSZ. Clayey alterations commonly found around the apatite-magnetite lenses are (12). Northern part of the study area constitutes of CGGC rocks whereas southern portion of the area constitutes of NSMB rocks. They are high grade rocks of gneiss with enclaves of granulite \& meta-sedimentary rocks and intrusive granite of Proterozoic age $(18,41)$. Younger intrusives of various composition ranging from mafic-ultramafic, sodic-ultra potassic alkaline rocks, anorthite and dolerite are present pervasively within CGGC. Mafic-ultramafic suites present are amphibolite, basic granulite and hornblendite. Other parts of the CGGC are covered by mica schist, phyllite and recent alluvial covers (Fig. 1).

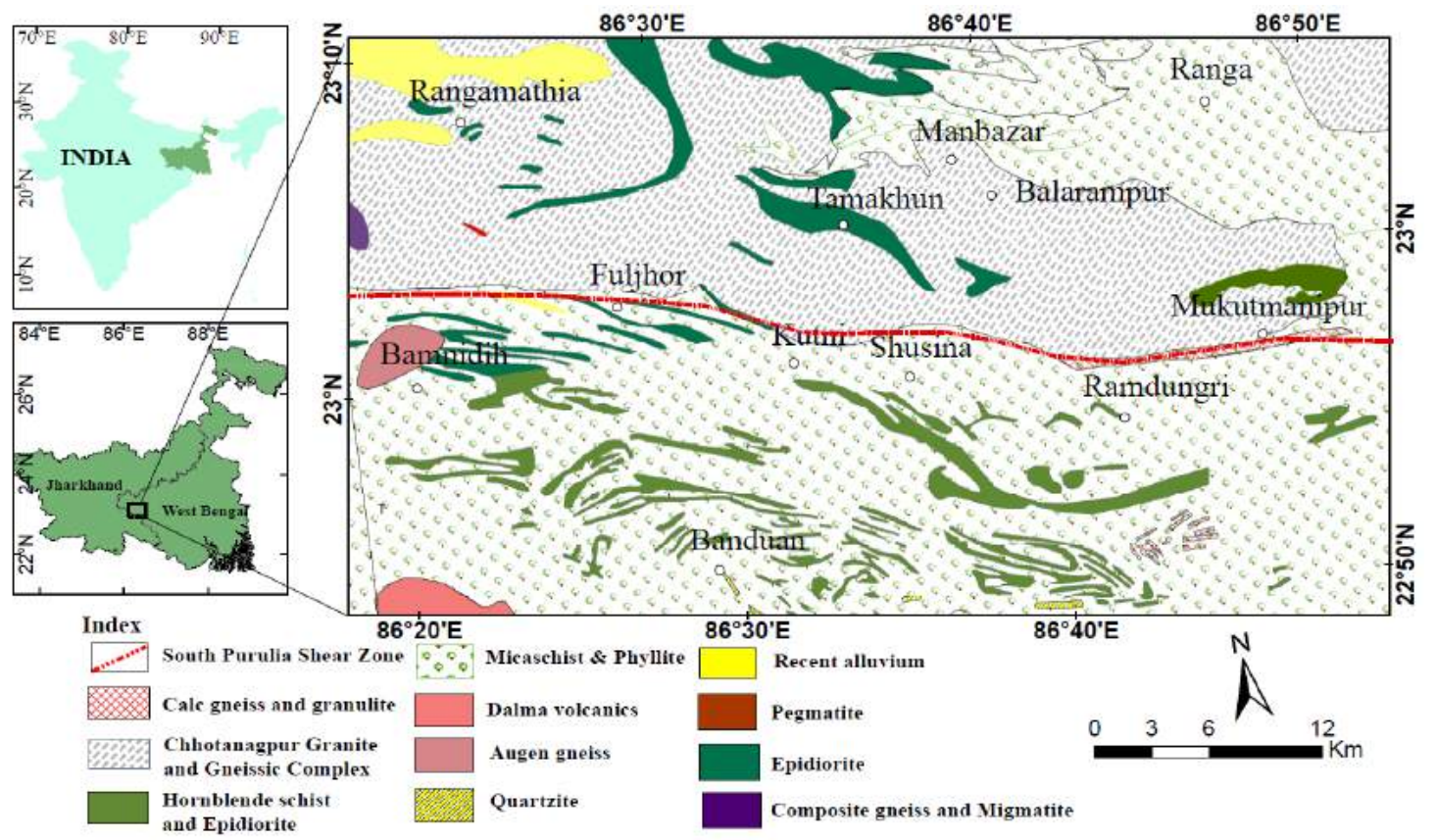

Fig. 1 Geological map of the study area.

\section{DATA AND METHODOLOGY}

ASTER (Advance Spaceborne Thermal Emission and Reflection Radiometer) dataset has been used for the current study. It provides information in 14 bands covering from visible to SWIR and TIR ranges; hence combinedly provide important information for alteration mineral (24). Details of resolution and wavelength have been listed in Table 1. Geological fieldwork, Google earth observations, band ratio and DPCA techniques have been employed for identifying the potential alteration zone in eastern end of SPSZ. For alteration mapping Band ratio and PCA are the most common techniques 


\title{
International Advanced Research Journal in Science, Engineering and Technology
}

\author{
Vol. 8, Issue 8, August 2021
}

\section{DOI: $10.17148 / I A R J S E T .2021 .8899$}

used in geoscience. In this study we have used band ratio and DPCA combinedly for alteration demarcation. Eigenvector loadings have been utilized for identifying alteration indicative DPC bands (or PCA of band ratios). Subsequently, using False Color Composition, thresholding and selective linear stretching, we have determined significant zones of alteration regionally. Instead of giving information about spectral properties like radiance and reflectance, DPCA provides information about the presence and enrichment of different minerals.

\subsection{Pre-processing of ASTER imagery}

Atmospheric correction was applied on ASTER dataset to convert the radiance data to Reflectance while eliminate the spectral effect of water vapours and aerosols. The resultant reflectance spectra can be directly compared with the laboratory or field reflectance spectra (40). After cross track illumination correction, ASTER dataset was converted to reflectance using FLAASH (Fast Line-of-sight Atmospheric Analysis of Spectral Hypercubes) algorithm. Considering maximum geological exposure, less vegetation coverage and fixed geology of an area over a small geological time period, the dataset chosen is from the year 2007. FLAASH parameters used are latitude and longitude of centre of scene $\left(23^{\circ} 05^{\prime}\right.$ $\left.13.56^{\prime \prime} \mathrm{N} \& 86^{\circ} 35^{\prime} 13.56^{\prime \prime} \mathrm{E}\right)$, date (12 ${ }^{\text {th }}$ January 2007), and time (04:54:36 GMT) of image acquisition, sensor altitude $(705 \mathrm{~km})$, initial visibility of the dataset $(60$, as the scene does not have a noticeable cloud cover), and average elevation of the area $(0.25 \mathrm{~km})$. The TIR data have been converted to emissivity using the Thermal atmospheric correction (19). The derived reflectance and emissivity data have been further used for band ratio and Relative Band Depths (RBDs).

\subsection{Band ratio and $R B D$}

Band ratio is the simple ratio between two bands which helps identifying the geological material of interest by reducing topographically induced brightness variations. Thus, ASTER band ratios have been applied with reflectance bands (B1B9) and emissivity data (B10 to B14) for demarcating different alterations. The mineral groups have been divided into three major groups viz. low temperature hydrothermal mineral assemblages (alunite, kaolinite, muscovite, biotite, illite, sericite, chlorite, pyrophyllite, calcite, epidote etc.); gossan or iron rich alteration (hematite, goethite, jarosite, limonite etc.); and others (mafic, silicates, and carbonate minerals) $(20,21,23,25)$ respectively. RBD is a similar approach like band ratio which forms three-point ratio formulation. RBD can better display absorption intensities such as, $\mathrm{Al}-\mathrm{O}-\mathrm{H}, \mathrm{Mg}-$ $\mathrm{O}-\mathrm{H}$, and $\mathrm{CO} 3$. For each absorption feature, the sum of the bands representing the shoulders is the numerator (band 1\&2), and the band representing the absorption feature minimum is the denominator (band 3), as shown in equation (1) (13). A high RBD value represents high absorption depth.

$$
R B D=\frac{\text { band } 1+\text { band } 2}{\text { band } 3}
$$

Table 1: Wavelength and spatial resolution of spectral bands of ASTER dataset.
Table 2: Band Ratio and RBDs for ASTER data used in the current study

\begin{tabular}{|c|c|c|c|c|c|}
\hline Band & Label & Wavelength & Resolution & Index & Band ratio/ RBD \\
\hline B1 & VNIR*Band1 & $0.520-0.600$ & 15 & Vegetation index & $(\mathrm{B} 3 * / \mathrm{B} 2)$ \\
\hline B2 & VNIR Band2 & $0.630-0.690$ & 15 & Gossan & (B4/ B2) \\
\hline B3 & VNIR Band3N & $0.760-0.860$ & 15 & Ferric iron oxide & (B2/ B1) \\
\hline B4 & SWIR**Band4 & $1.600-1.700$ & 30 & Ferrous iron oxide & (B1/ B22) \\
\hline B5 & SWIR Band5 & $2.145-2.185$ & 30 & Kaolinite & (B7/ B5) \\
\hline B6 & SWIR Band6 & $2.185-2.225$ & 30 & Alunite/ kaolinite/ pyrophyllite & $((\mathrm{B} 4+\mathrm{B} 6) / \mathrm{B} 5)$ \\
\hline B8 & SWIR Band8 & $2.295-2.365$ & 30 & Illite/ smectite/ muscovite & $((\mathrm{B} 5+\mathrm{B} 7) / \mathrm{B} 6)$ \\
\hline B9 & SWIR Band9 & $2.360-2.430$ & 30 & Phengite & (B5/ B6) \\
\hline B10 & TIR $* * *$ Band 10 & $8.125-8.475$ & 90 & Carbonate/ chlorite/ epidote & $((\mathrm{B} 7+\mathrm{B} 9) / \mathrm{B} 8)$ \\
\hline B11 & TIR Band11 & $8.475-8.825$ & 90 & Skarn carbonate & (B13/ B14) \\
\hline B12 & TIR Band 12 & $8.925-9.275$ & 90 & Dolomite & $((\mathrm{B} 6+\mathrm{B} 8) / \mathrm{B} 7)$ \\
\hline B13 & TIR Band 13 & $10.250-$ & 90 & Silica & (B13/ B10) \\
\hline B14 & TIR Band14 & $10.950-$ & 90 & Amphibolites & $((\mathrm{B} 6+\mathrm{B} 9) / \mathrm{B} 8)$ \\
\hline \multicolumn{4}{|c|}{$\begin{array}{l}\text { * Visible Near InfraRed; **Short-Wave InfraRed; } \\
* * * \text { Thermal InfraRed }\end{array}$} & $\begin{array}{l}\text { Epidote/ chlorite/ } \\
\text { Garnet/ pyroxene } \\
\text { Carbonate }\end{array}$ & $\begin{array}{l}((\mathrm{B} 6+\mathrm{B} 9) / \\
(\mathrm{B} 12 / \mathrm{B} 13) \\
(\mathrm{B} 13 / \mathrm{B} 12)\end{array}$ \\
\hline
\end{tabular}


DOI: 10.17148/IARJSET.2021.8899

Amphiboles

(B6/ B8)

*Abbreviation described in Table 1

ASTER sensor has 14 bands allowing many permutation combinations of band ratios and RBDs for identification and mapping of different minerals and lithology $(28,29,30,36,37,44)$. In the present study, we have used band ratios and RBDs for three major alteration mineral assemblages, i.e., low temperature hydrothermal (kaolinite, illite-smectitemuscovite, alunite-kaolinite-pyrophyllite, silica, ferrous, ferric, carbonate, carbonate-chlorite-epidote) and gossanized zone (ferrous, ferric, gossan); and for unaltered host rocks (silica, garnet-pyroxene, amphibolite, dolomite) as given in the Table 2. The standard deviation-based classification demarcates anomalous zone with extremely high values from the average background statistically and significantly (using formula "average + $[2.625 \mathrm{X}$ standard deviation]"). Therefore, all band ratios have been classified using $1 / 4^{\text {th }}$ standard deviation classification scheme in order to highlight the relative abundance of different indexes in a single map, while minimizing overlapping area for individual band ratio results $(14,23)$.

\subsection{Directed Principal Component Analysis (DPCA)}

Directed Principal Component Analysis (DPCA) is the principal component analysis (PCA) of different band ratios. In the current study vegetation index is used as an important index for its implication in separation of the vegetation effect from the alteration representative index. DPC analysis was performed on the 17 spectral indexes including vegetation represented in Table 2. These 17 indexes have been used to map different minerals present in the study area and to find the best possible DPC combination for alteration zone demarcation. The DPC having loadings of similar signs on two band ratio images explains the variance due to the similarities in the spectral response, whereas the DPC, whose loadings are different signs on either band ratio images highlights the contribution unique to each of the component. The loading varies ideally from -1 to 1 ; areas of strong positive association represented by pixels with brighter shade show positive loadings, while pixels with darker shade show negative loading indicates an inverse relation of DPC with the input band (17). Eigenvector matrix was computed from the covariance matrix of the original image. Both the eigenvector matrix and eigenvector image represent the DPC results calculated using the covariance matrix of band ratios. Each DPC represents the weighted linear combination of original band ratios and the eigenvector represents the weight in the transformations collectively $(11,23)$.

$$
\begin{gathered}
\mathrm{DPC} 1=\mathrm{W} 11(\text { Band } 1)+\mathrm{W} 12(\text { Band2 })+\mathrm{W} 13(\text { Band3 })+\ldots+\mathrm{W} 1 \mathrm{n}(\text { Bandn }) \\
\mathrm{DPC} 2=\mathrm{W} 21(\text { Band })+\mathrm{W} 22(\text { Band2) }+\mathrm{W} 23(\text { Band3 })+\ldots+\mathrm{W} 2 \mathrm{n}(\text { Bandn }) \\
\ldots \ldots . \\
\mathrm{DPCn}=\mathrm{Wn} 1(\text { Band } 1)+\mathrm{Wn} 2(\text { Band2) }+\mathrm{Wn} 3(\text { Band3 })+\ldots+\mathrm{Wnn}(\text { Bandn })
\end{gathered}
$$

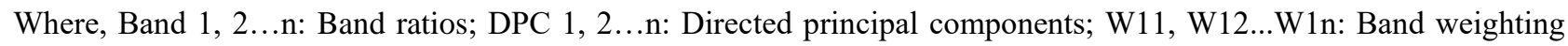
coefficients for DPC1; W21, W22...W2n: Band weighting coefficients for DPC2... DPCn; Wn1, Wn2 .... Wnn: Band weighting coefficients for DPCn.

\subsection{Identification of geomorphic features}

The simple band combination technique can highlight the larger exposed hydrothermal alterations with different SWIR images. However, for the tropical regions, interpretations are not straight forward. Therefore, here we have demarcated different geomorphic and anthropogenic features present in the study area from the GeoEye satellite view (Fig. 2) for making interpretation simpler. Features identification from GeoEye view have been carried out before field work to draw some preliminary knowledge on important alteration zones. Some of the zones are further validated with the field observations. The aerial view of different geomorphic and anthropogenic features has been given in Fig. 2. Figure 3 provides spatial distribution of these geomorphic features superimposed on the lithology map. 
DOI: $10.17148 /$ IARJSET.2021.8899
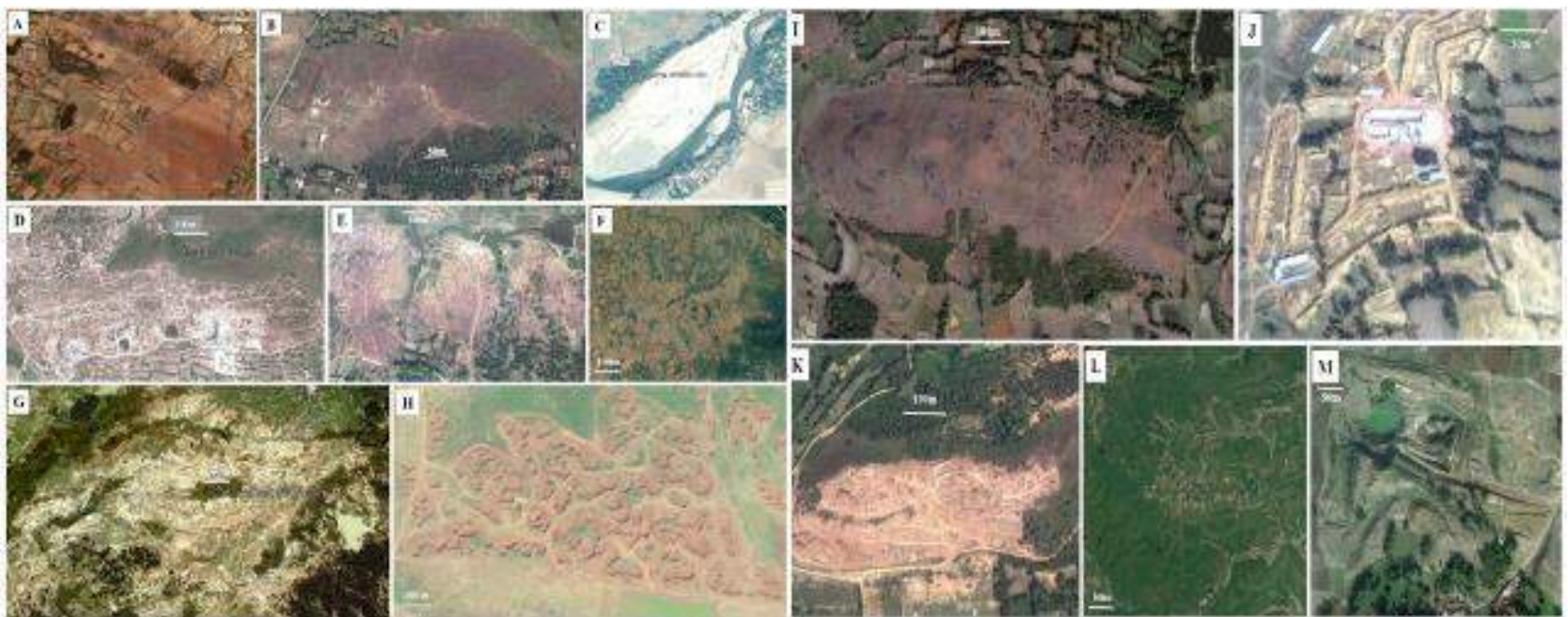

Fig. 2 Types of geomorphic and anthropogenic features marked from GeoEye satellite view such as, Partially excavated lateritic exposure (A, H), Gossan (B, I), river bank (C), Excavated zone (D, K), Recent alluvium (E, G), Alluvial fan (F), Clay bricks plant (J), Highly vegetated hills (L), Open caste mines (M).

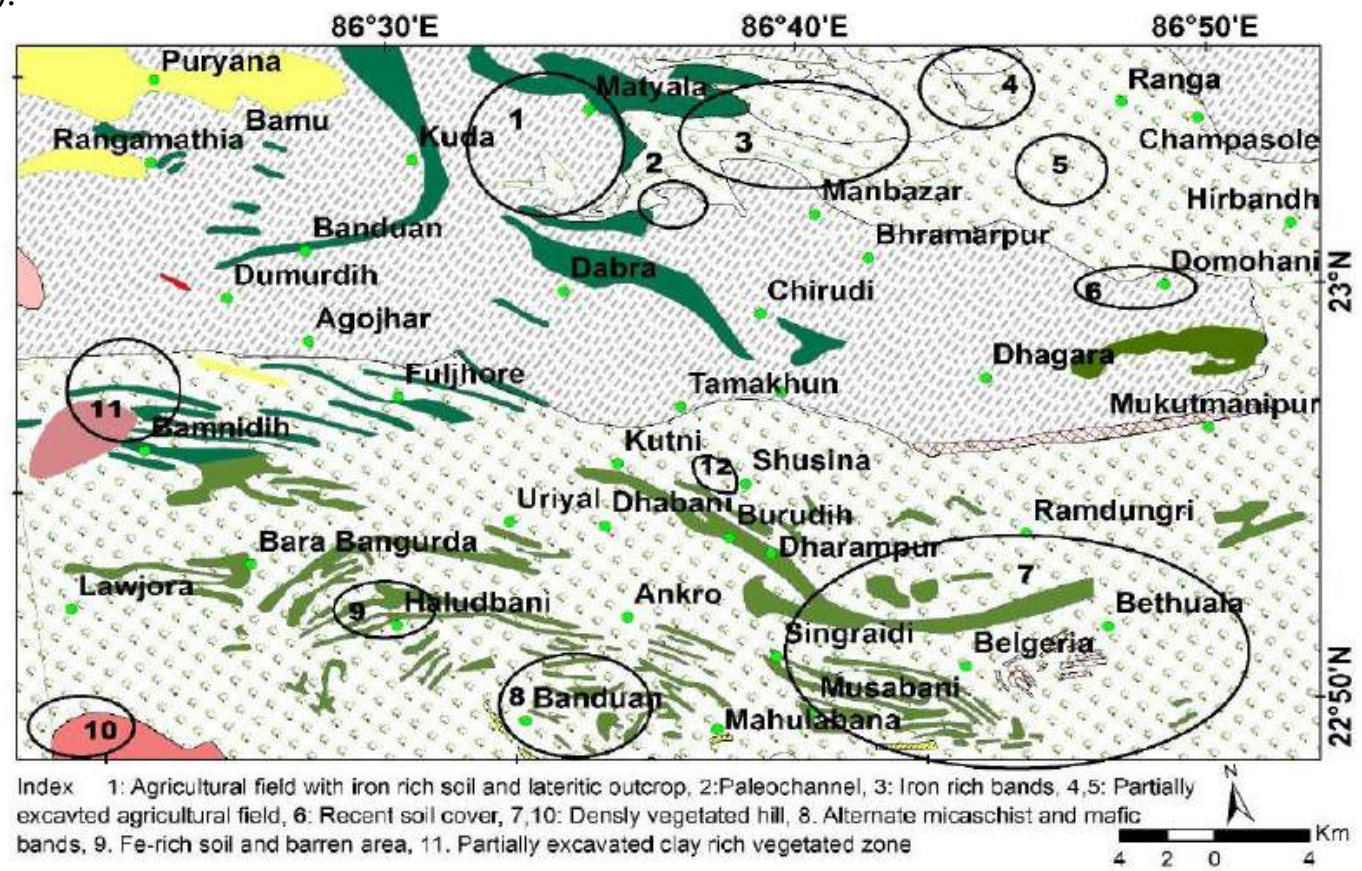

Fig. 3 Geomorphic and anthropogenic features marked in the study area. Circles with numbers represent different observations, as shown in legend.

\subsection{Band ratio result}

\section{RESULT AND DISCUSSION}

Fig. 4 shows distribution of different minerals derived from the band ratio result. High concentration of silica and iron oxide index were observed compared to clay and mica index. Northern region (Fig. 4) shows high concentration of iron rich minerals. River channel areas show high concentration for silica and iron rich minerals. The northwest corner of the scene shows high concentration of iron and silica minerals is correspond to the recent alluvium covered region. Silica rich zones identified are correspond to the high silica rich zone of granite and gneiss, quartzite, quartz or mica schist, and vein quartz. Alteration zone present near the shear zone boundary show enrichment of alteration mineral group clay, iron, mica, and chlorite groups (Fig. 4) along with subordinate amount of quartz. Other areas showing similar assemblages of alteration mineral index have been marked includes $2,4,5,7,8,10,11$. High concentration of clay and mica representing region near Belgeria (7) correspond to the altered mafic bands and mica schist bands. The region 2, 4 and 5 corresponds to the ferruginous and altered mica schist and clay band regions. High concentration of quartz and iron rich minerals have 


\title{
International Advanced Research Journal in Science, Engineering and Technology
}

\author{
Vol. 8, Issue 8, August 2021
}

\section{DOI: 10.17148/IARJSET.2021.8899}

been observed from 1, 3, and 6 corresponds to the ferruginous mica and quartz schist regions mostly. Some unaltered mafic areas show high concentration of garnet and pyroxene index (8, 9, near Kutni and Banduan).

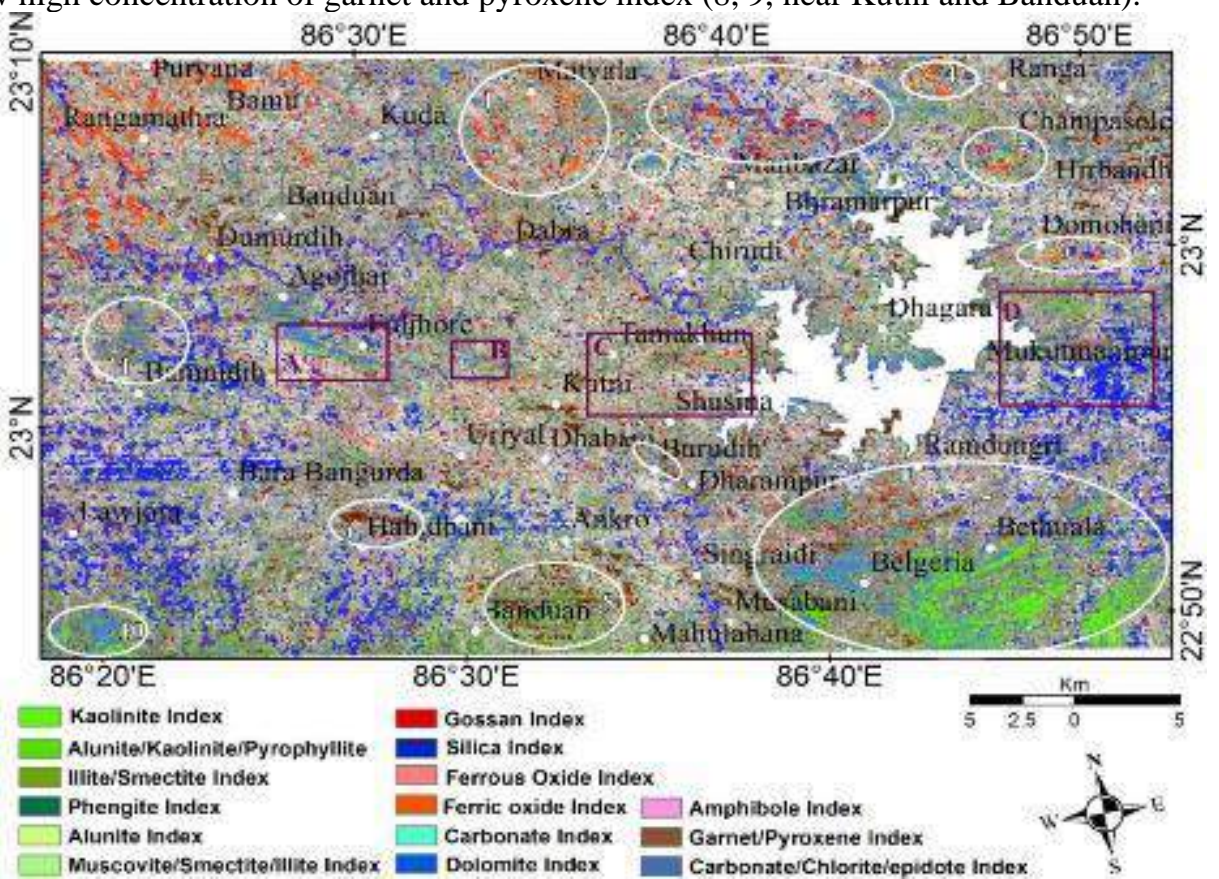

Fig. 4 Remotely derived hydrothermal alteration map showing distribution of chlorite, clay and mica groups of minerals with green shade; iron rich zone including gossan with shades of red; and silica dominated pixels with blue colour.

Alteration zone is more extensive and exposed in Mukutmanipur area (Fig. 4D), which might be the reason the area gets highlighted better than other alteration zones present near SPSZ boundary. Quartzite hill overprinted by the ferruginisation and alteration show high concentration of clay, chlorite, epidote and mica rich, and iron rich patches trending NNW-ESE. However, the quartzite band is not showing high concentration for silica index. Zoom box-B (Fig. 4) also shows similar assemblage of chlorite, mica and clay minerals with less amount of iron and silica minerals. In Tamakhun-Thakurdungri region (Fig. 4C), alteration zones are showing high concentration of iron and clay, with moderate concentration of mica and quartz. Some area also shows enrichment of garnet and pyroxene. Iron is the most dominant index here, as ferruginisation is the most dominant type of alteration of the region followed by argillisation, silicification, sericitization, and chloritization.

\subsection{DPCA results}

Eigenvector loadings are used for understanding the contribution of original band for the DPC band. Based on this we have mapped different alteration mineral distribution. The green and red shade represents the high positive loading factor and high negative loading factors respectively (Table 3).

Table-3 Statistical summary of DPCA with details of eigen vector loading for different indexes. Green color represents positive loading and red color shade indicates negative loading.

*Index; 1: vegetation, 2: gossan, 3: ferric iron oxide, 4: ferrous iron oxide, 5: illite/smectite, 6: kaolinite, 7: amphibole, 8: skarn carbonate/epidote, 9: alunite/kaolinite, 10: amphibole, 11: biotite/amphibole/chlorite index, Index-12: carbonate/chlorite/epidote index, Index-13: dolomite index, Index-14: garnet/pyroxene index, Index15: muscovite/smectite index, Index-16: phengite index, Index-17: silica index.

Table-3 Statistical summary of DPCA with details of eigen vector loading for different indexes. Green color represents positive loading and red color shade indicates negative loading. 


\title{
International Advanced Research Journal in Science, Engineering and Technology
}

\author{
Vol. 8, Issue 8, August 2021
}

\section{DOI: $10.17148 /$ IARJSET.2021.8899}

*Index; 1: vegetation, 2: gossan, 3: ferric iron oxide, 4: ferrous iron oxide, 5: illite/smectite, 6: kaolinite, 7: amphibole, 8: skarn carbonate/epidote, 9: alunite/kaolinite, 10: amphibole, 11: biotite/amphibole/chlorite index, Index-12: carbonate/chlorite/epidote index, Index-13: dolomite index, Index-14: garnet/pyroxene index, Index15: muscovite/smectite index, Index-16: phengite index, Index-17: silica index.

\begin{tabular}{|c|c|c|c|c|c|c|c|c|c|c|c|c|c|c|c|c|c|}
\hline & DPCl & $\mathrm{PC2}$ & $\mathrm{DPC3}$ & PC4 & DPC5 & PC6 & DPC7 & DPCS & DPC9 & $\begin{array}{r}\text { DPCl } \\
0\end{array}$ & $\begin{array}{r}\mathrm{DPCl} \\
1\end{array}$ & $\begin{array}{r}\mathrm{PCl} \\
2\end{array}$ & $\begin{array}{r}\mathrm{PCl} \\
3\end{array}$ & $\begin{array}{r}\text { DPC1 } \\
4\end{array}$ & $\begin{array}{r}\text { DPCl } \\
5\end{array}$ & $\begin{array}{r}\mathrm{PCI} \\
6\end{array}$ & $\begin{array}{r}\mathrm{PPCl} \\
7\end{array}$ \\
\hline Index 1 & 0.781 & 279 & 311 & 0.089 & 004 & 0.155 & 0.254 & 0.221 & 0.181 & 0.178 & 0028 & 0.003 & 0.004 & 0.004 & 0002 & 0.001 & 0 \\
\hline Index-2 & 0.124 & 0.697 & 0.554 & -0.248 & -0.026 & -0.055 & -0.072 & -0.214 & 0.129 & -0.24 & -0.021 & 0.001 & 0 & -0.004 & -0.003 & -0.001 & 0 \\
\hline Index-3 & 0.178 & 0.061 & -0.028 & 0.134 & 0.018 & -0.174 & 0.903 & -0.305 & 0.066 & -0.044 & 0.01 & -0.003 & -0.018 & -0.003 & 0.001 & 0 & 0 \\
\hline Irdex -4 & -0.357 & $0.10 \mathrm{~s}$ & 0.354 & -0.243 & -0.031 & 0.22 & 0.197 & 0.381 & 0.416 & 0.519 & 0.026 & -0.01 & -0.014 & 0.004 & 0.006 & 0.002 & 0 \\
\hline Index-5 & 0.061 & -0.178 & -0.083 & -0.524 & -0.005 & -0.153 & -0.033 & -0.358 & -0.022 & 0.215 & -0.041 & 0.007 & 0.263 & 0.26 & 0.104 & -0.029 & 0.577 \\
\hline Index-6 & -0.039 & 0.041 & -0.016 & 0.025 & 0.016 & -0.373 & 0.03 & 0.304 & -0.327 & -0.343 & 0.058 & -0.004 & 0.297 & $0.45 !$ & -0.492 & 0.033 & 0 \\
\hline Inder-7 & 0.057 & .0012 & 0169 & 0163 & .00019 & 0027 & 0085 & 03337 & 0629 & 0221 & -0051 & 001 & 0722 & 0363 & D) 161 & 0334 & 0 \\
\hline Inder-8 & -10.004 & 0000 & 0.016 & 0024 & 0574 & 0023 & 0.004 & 0.012 & 0 & 0 & 0.053 & 0.816 & -0005 & -10.004 & 0.001 & 9 & 0 \\
\hline Ioder-9 & 0.07 & 022 & 0.037 & 0495 & 0.043 & A513 & -0) 212 & -0.234 & -0.171 & 0.549 & 0.054 & 0.005 & 0.008 & 0.006 & 0.004 & 0002 & 0 \\
\hline Index-10 & 0.296 & .0345 & 0.472 & 0.21 & 0.005 & 0.112 & 0.079 & 0.024 & 0.017 & 0.008 & .013 & 0.004 & 0.057 & 0.178 & 0.018 & .0687 & 0 \\
\hline Index-11 & 01 & 0118 & 0.153 & 0.158 & $\$ 0001$ & 0251 & -0.019 & 024 & 0.282 & (4). 1 & 0021 & .0 .001 & 0.463 & $0 \leqslant 67$ & 0.186 & 0394 & 0 \\
\hline Inder-12 & 0.308 & 0.411 & 0422 & -0031 & 0.001 & -0174 & 0074 & $-10,027$ & 4. 171 & -12072 & 00019 & -6001 & 0173 & -0.458 & p0.771 & 0492 & a \\
\hline Index -13 & -0.085 & 0.144 & .0 .064 & 0309 & 0.004 & 0.523 & -0.046 & -03 & 0.233 & -0.068 & 0.006 & 0.006 & 0.657 & -0.03 & 0.042 & 0.072 & 0 \\
\hline Index 14 & 0.005 & $0.00^{\circ}$ & 0.027 & 0.014 & 0.537 & 0.016 & 0.032 & 0.045 & 0.066 & 0.057 & 072 & 0.425 & 0.019 & 0.005 & 0.005 & 0001 & 0 \\
\hline Index-15 & 0.009 & -0.063 & -0.05 & -0.24 & 0.006 & -0.282 & -0.002 & -0.004 & -0.186 & -0.088 & 0.019 & -0.002 & 0.24 & 0.121 & 0.632 & -0.089 & -0.577 \\
\hline Index-16 & 0.052 & -0.115 & -0.034 & -0.285 & -0.011 & 0.13 & -0.03 & -0.354 & 0.164 & 0.303 & -0.06 & 0.009 & 0.023 & 0.139 & -0.529 & 0.06 & -0.577 \\
\hline Index -17 & -0.003 & 0.001 & 0.004 & -0.029 & 2.614 & 0.033 & 0.021 & 0.03 & -0.043 & -0.049 & -0.678 & -0.391 & -0.011 & -0.001 & 0.003 & 0.001 & 0 \\
\hline
\end{tabular}

The thresholded DPC result (Fig. 5) extracted with $1 / 4^{\text {th }}$ standard deviation classification scheme highlights the trend of alteration zone observed in East-West to ESE-WNW following the shear zone trend. The ferruginous clay alteration zones mostly composed of clay and iron minerals are occur as patches mostly trending E-W to ESE-WNW. River channel areas are showing enrichment of silica and clay with occasionally iron bearing minerals. Silica rich zone correspond to the exposed region of granite, gneiss, quartzite and vein quartz region (Fig. 5). The zoom box 'A' (Fig. 5A), Fuljhor region shows high concentration of iron and clay minerals in the central zone represents the highly brecciated quartzite overlain by clay bands to the south. However, the quartzite band is not highlighted in this region. To NW corner of the area enrichment of clay and mica groups minerals represented by green and yellow shades represent the mica schist exposure. Zoom box B (Fig. 5B), Jiling region show the enrichment of clay and iron minerals correspond to the clay, iron and mica rich bands. Here also the quartz rich zones are not highlighted. In Tamakhun-Thakurdungri region (Zoom box C) intense alteration zones present as barren mounts are highlighted with yellow colours, mostly composed of highly altered product of clay, iron and mica group of minerals. The green colour patches also represent alteration products. Variation of alteration products is very complex in this region. Some of the silica bands have been highlighted here.

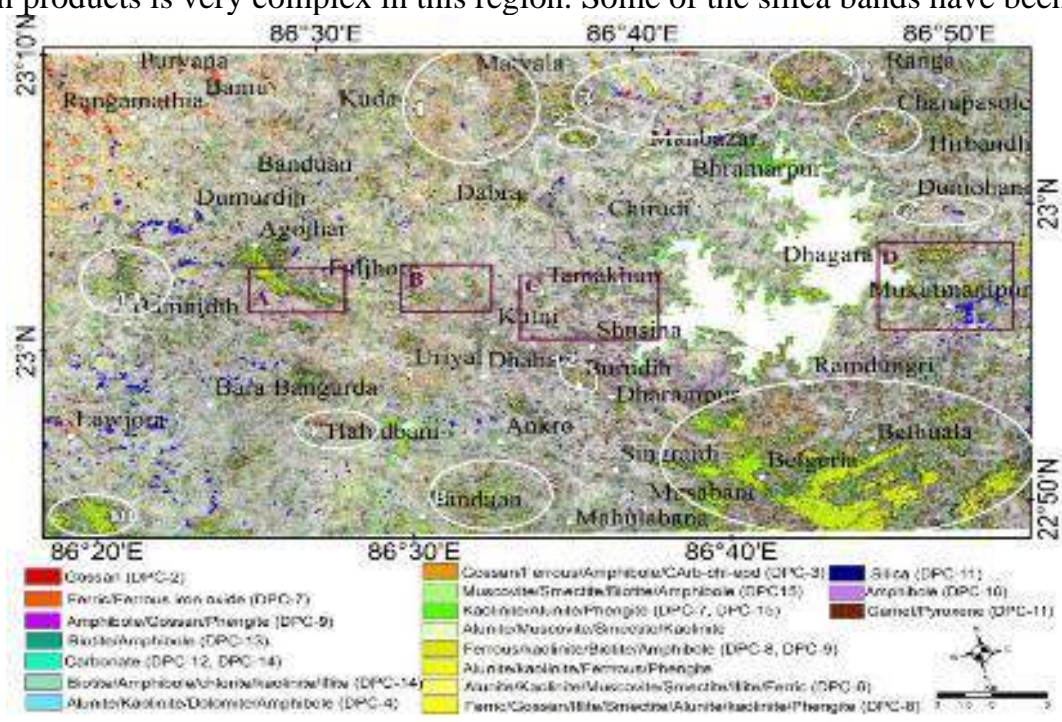

Fig. 5 Spatial distribution of alteration minerals resulted from DPC after thresholding. DPCs are interpreted as per indicative mineral assemblages observed from Eigenvector loading. 


\title{
International Advanced Research Journal in Science, Engineering and Technology
}

\author{
Vol. 8, Issue 8, August 2021
}

\section{DOI: $10.17148 /$ IARJSET.2021.8899}

Best demarcation of alteration assemblages is observed in the Mukutmanipur region (Zoom box D). Here all the alteration assemblages including clay, iron, mica, chlorite, and silica group of minerals have been highlighted prominently. Major alteration composition of the area is clay, mica and iron as observed from the field and DPCA result both (Fig. 6D). Silica rich zone present towards the south are the exposed zone of granite and gneiss. Some of the zones showing enrichment of different minerals have been demarcated. Demarcated area 7, 8, and 10 represents the altered mafic bands of Singhbhum group and Dalma volcanics show high concentration of mica, clay, chlorite and iron group of minerals. Some part of mica schist and calc-granulite also shows this type of enrichment as observed in 7 . The north western corner of the scene showing enrichment of iron and clay minerals are mostly the lowland area covered by recent alluvium. Enrichment of silica and iron with small amount of clay and mica have been observed from region of highly ferruginised and weathered quartz and mica schist $(1,3,6)$. Other mica rich altered schist bands showing high concentration of clay, mica and iron group of minerals $(2,4,5,11)$. Garnet and pyroxene rich zone as marked by 9 represents the hornblende schist band present in that region. Low concentration of carbonate and amphibole minerals distribution have been observed from few small regions.

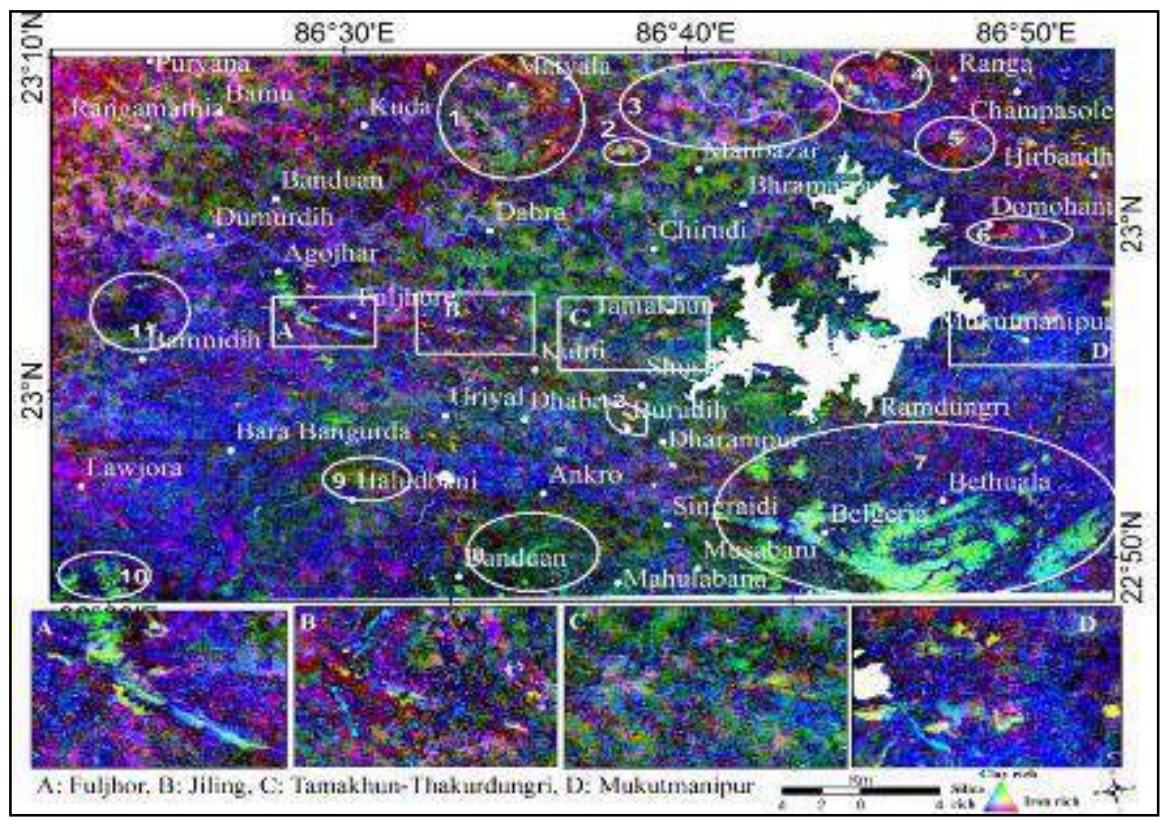

Fig. 6 RGB band combination with thresholding and linear stretching of DPC 7-10-11. Clay and iron-rich zones are highlighted here with light green and yellow colour, whereas silica and iron-rich zones as blue and red colour respectively.

RGB combination of DPC-7, DPC-10 and negative image of DPC-11 as R_G_B highlights the silica, and iron rich zone with blue, and red colours (Fig. 6). These DPC bands have been selected for highlighting alteration zone, considering the high contribution of iron oxide bearing index, clay representative index and silica index with very small or negligible contribution of vegetation index for the DPC bands. Yellow and green colour represents both clay and/or iron rich zone (Fig. 6). Figure 6 also clearly highlights and demarcate all alteration zone identified from thresholded DPC result. All the four zoom boxes marked as A, B, C, and D have been interpreted as important alteration zone near SPSZ.

\subsection{Field evidences of alteration}

Hydrothermal alteration zones occur all along the shear zone as discrete lensoid patches, strikes parallel to the shear zone. Common mineral assemblages include white mica, sericite, clay (montmorillonite, kaolinite, notronite and illite), ferruginous clay, quartz, and iron bearing minerals (limonite, hematite, goethite). Important alteration zones have been identified from field visit along the shear zone from the places Fuljhor (Fig. 7A), Tamakhun (Fig. 7B), Thakurdungri (Fig. 7C), and Mukutmanipur (Fig. 7D). Similar assemblages of altered rocks have been found from all four places. Mukutmanipur marks the eastern extremity of alteration zone of SPSZ. Geoeye and field observations suggest that Mukutmanipur alteration zone as the possible extension of Tamakhun-Thakurdungi alteration zone. Near Mukutmanipur, alteration zone forms wide exposure covering a minimum of $2 \mathrm{~km}$ long and $1 \mathrm{~km}$ wide in this region. Altered rock assemblages present in the area includes brecciated and ferruginised quartzite, laterite, ferruginised schist, mica schist/ phyllite, pure- ferruginous clay, and quartz muscovite sericite schist (Fig 7). Alteration zone is well 


\section{DOI: $10.17148 /$ IARJSET.2021.8899}

preserved in Tamakhun-Thakurdungri area. All alteration lithounits are vertical and E-W to WNW-ESE trending parallel to the shear zone.
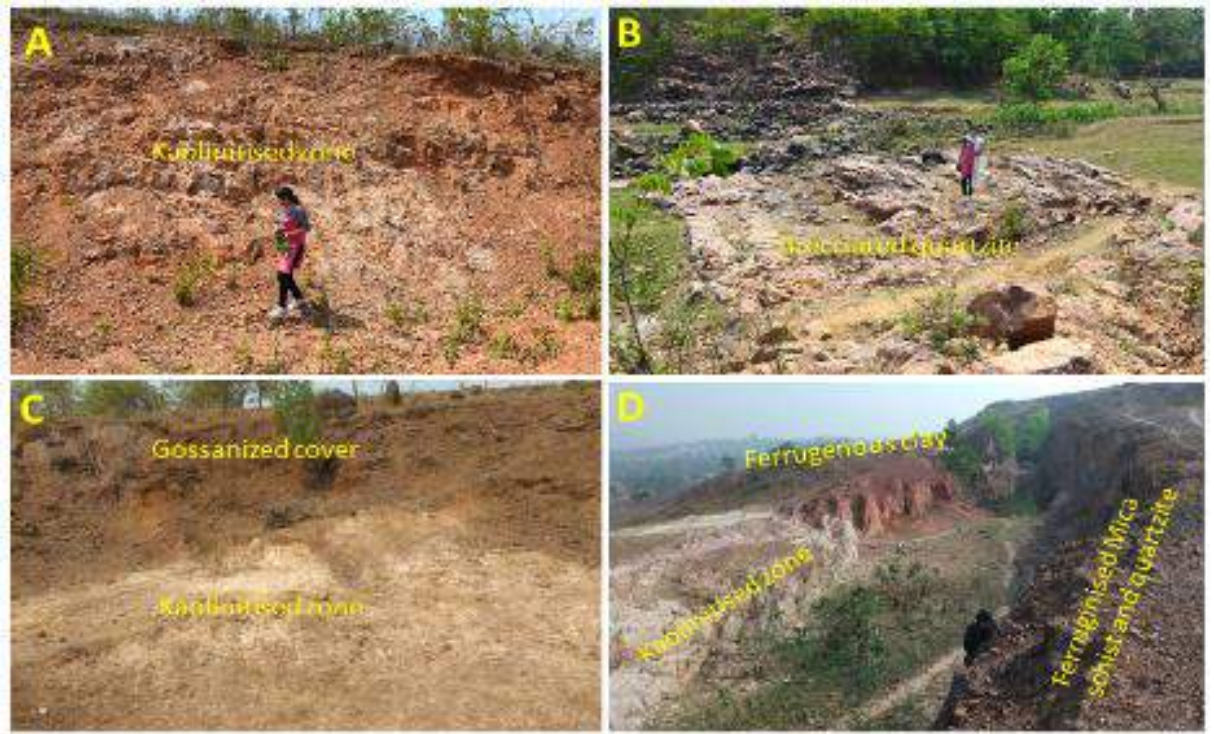

Fig. 7 Field photographs showing alteration zone observed from Fuljhor (A, B), Thakurdungri hill (C), and Mukutmanipur (D). The dominant alteration found are brecciated/ ferruginised quartzite, gossanized zone, kaolinitised zone and ferruginised to pure mica schist.

\subsection{Accuracy assessment of DPC result}

Accuracy of the DPC results was computed considering the match between the field evidences and the DPC results. The field evidences collected from a random stratified sampling pattern is used in the current study. Light green, light cyan and yellow colour pixels (Fig. 5, Fig. 6) of DPC results represents presence of clay and iron-bearing were considered as hydrothermal alteration zone and other areas as an unaltered zone. The blue and red colour represents silica rich and iron rich zone respectively. Both DPC results, $14^{\text {th }}$ standard deviation classification scheme, and RGB combination with selective thresholding and linear stretching techniques have similar accuracy $79.31 \%$ (69/87) and $77.01 \%$ (67/87) respectively. The alteration zones present are of small scale and mostly covered by vegetation. Both DPCA results have more user's accuracy than producer's accuracy. All the main domains of alteration are well demarcated with both techniques. False positive error is comparatively less in RGB based interpretation of DPC result than the thresholded DPCA result.

\section{CONCLUSION}

This chapter provides clear support for remote detection of alterations, despite many sources of heterogeneity due to dense vegetation, anomalous soil moisture along river channels and other anthropogenic activities like agriculture, dams, reservoirs, excavations. It gives necessary information about the extension and distribution of alteration zones with minerals like clay, gossan, mica, silicate, carbonate etc. in eastern part of SPSZ. Therefore, further exploration and adoption of appropriate management strategies for vegetated tropical zones would be easier to adopt by exploration companies. Alteration zones occur as irregular patches limited to the shear zone, with a trend varies from E-W to ESEWNW as clearly evidence from results. Common varieties of alteration mineral assemblages present are clay, mica and iron group. Distribution of chlorite group and carbonate group of minerals are less compared to other groups. The exposed and excavated mining areas exhibit good correlation for both band ratio and DPCA results. Such areas got homogeneous pixels in comparison to the sparsely vegetated and unexposed area. The DPCA method is able to extract partial information on mineral assemblages present for the highly vegetated zones by suppressing the vegetation effect partially. However, it fails to remove the total effect of vegetation from an area. Based on both band ratio and DPCA results, few zones have been identified as important which seeks further studies for detailed alteration mapping, and mineral potentiality mapping using more confirmative methods. Places such as, Fuljhor (Fig. 6A), Jiling (Fig. 6B), TamakhunThakudungri (Fig. 6C), and Mukutmanipur (Fig. 6D) have been identified as important alteration zones. 


\title{
International Advanced Research Journal in Science, Engineering and Technology
}

\author{
Vol. 8, Issue 8, August 2021
}

\section{DOI: 10.17148/IARJSET.2021.8899 \\ ACKNOWLDGEMENT}

This research was funded by SRIC, IIT Kharagpur, with institute start-up grant (ISIRD). PM is thankful for the support from MHRD.

\section{REFERENCES}

1. Abedi, M., Torabi, S.A., and Norouzi, G.H. (2013). Application of fuzzy AHP method to integrate geophysical data in a prospect scale, a case study: Seridune copper deposit. Bollettino di Geofisica Teorica ed Applicata, 54(2).

2. Acharyya, A., Ray, S., Chaudhuri, B.K., Basu, S.K., Bhaduri, S.K., and Sanyal, A.K. (2006). Proterozoic rocksuites along South Purulia Shear Zone, eastern India: Evidence for rift-related setting. Geological Society of India, 68(6), 1069-1086.

3. Basu, S.K. (2003). Petrogenetic model for evolution of Alkaline-Carbonatite Complex along Tamar-Porapahar Shear Zone in North Singhbhum Proterozoic Mobile Belt, Eastern India and its metallogenic aspects. Journal-Geological Society of India, 62(2), 250-252.

4. Bhattacharya, H.N., and Mahapatra, S. (2008). Evolution of the Proterozoic rift margin sediments-North Singhbhum Mobile belt, JharkhandOrissa, India. Precambrian Research, 162(1-2), 302-316.

5. Bhattacharya, S., Majumdar, T.J., Rajawat, A.S., Panigrahi, M.K., and Das, P.R. (2012). Utilization of Hyperion data over Dongargarh, India, for mapping altered/weathered and clay minerals along with field spectral measurements. International journal of remote sensing, 33(17), 5438-5450.

6. Bhattacharyya, C., Borty, A.C., and Banerjee, P.K. (1991). Petrology-geochemistry of apatite-magnetite amphibolites and their role in phosphate mineralization along the Southern shear zone, Puruliya district. West Bengal. Indian journal of earth sciences, 18(2), 94-109.

7. Bishop, C.A., Liu, J.G., and Mason, P.J. (2011). Hyperspectral remote sensing for mineral exploration in Pulang, Yunnan Province, China. International Journal of Remote Sensing, 32(9), 2409-2426.

8. Carranza, E.J.M., and Hale, M. (2002c). Wildcat mapping of gold potential, Baguio district, Philippines. Applied Earth Science, 111(2), 100105 .

9. Chakrabarty, A., and Sen, A.K. (2010). Enigmatic association of the carbonatite and alkali-pyroxenite along the Northern Shear Zone, Purulia, West Bengal: A saga of primary magmatic carbonatite. Journal of the Geological Society of India, 76(4), 403-413.

10. Chakrabarty, A., Sen, A.K., and Ghosh, T.K. (2009). Amphibole - a key indicator mineral for petrogenesis of the Purulia carbonatite, West Bengal, India. Mineralogy and Petrology, 95(1-2), 105-112.

11. Chang, H., and Yoon, W.S. (2003). Improving the classification of Landsat data using Standardized principal components analysis. KSCE Journal of Civil Engineering, 7(4), 469-474.

12. Chatterjee, P., De, S., Ranaivoson, M., Mazumder, R., and Arima, M. (2013). A review of the 1600 Ma sedimentation, volcanism, and tectono-thermal events in the Singhbhum craton, Eastern India. Geoscience Frontiers, 4(3), 277-287.

13. Crowley, J.K., Brickey, D.W., and Rowan, L.C. (1989). Airborne imaging spectrometer data of the Ruby mountains Montana: mineral discrimination using relative absorption band-depth images. Remote Sensing of Environment, 29, 121-134.

14. De Smith, M.J., Goodchild, M.F., and Longley, P. (2007). Geospatial analysis: a comprehensive guide to principles, techniques and software tools. Troubador Publishing Ltd.

15. Di Tommaso, I., and Rubinstein, N. (2007). Hydrothermal alteration mapping using ASTER data in the Infiernillo porphyry deposit, Argentina. Ore Geology Reviews, 32(1-2), 275-290.

16. Ducart, D.F., Silva, A.M., Toledo, C.L.B., and Assis, L.M.D. (2016). Mapping iron oxides with Landsat-8/OLI and EO-1/Hyperion imagery from the Serra Norte iron deposits in the Carajás Mineral Province, Brazil. Brazilian Journal of Geology, 46(3), $331-349$.

17. Fraser, S.J., and Green, A.A. (1987). A software defoliant for geological analysis of band ratios. International Journal of Remote Sensing, $8,525-532$.

18. Ghose, N.C, Mukherjee, D. and Chatterjee, N. (2005). Plume generated Mesoproterozoic mafic-ultramafic magmatism in the Chotanagpur mobile belt of eastern Indian shield margin. J. Geol. Soc. India, 66, 725-740.

19. Gillespie, A., Rokugawa, S., Matsunaga, T., Cothern, J.S., Hook, S., and Kahle, A.B. (1998). A temperature and emissivity separation algorithm for Advanced Spaceborne Thermal Emission and Reflection Radiometer (ASTER) images. IEEE transactions on geoscience and remote sensing, 36(4), 1113-1126.

20. Halder, S.K. (2013). Mineral exploration: Principle and application, Elsevier Publication, https://doi.org/10.1016/C2011-0-05550-3, pp 62.

21. Hunt, G.R., and Ashley, R.P. (1979). Spectra of altered rocks in the visible and near infrared. Economic Geology, 74(7), 1613-1629.

22. Kruse, F.A. (1988). Use of airborne imaging spectrometer data to map minerals associated with hydrothermally altered rocks in the northern grapevine mountains, Nevada, and California. Remote Sensing of Environment, 24(1), 31-51.

23. Mahanta, P., and Maiti, S. (2018). Regional scale demarcation of alteration zone using ASTER imageries in South Purulia Shear Zone, East India: Implication for mineral exploration in vegetated regions. Ore Geology Reviews, 102, 846-861.

24. Mars, J.C., and Rowan, L.C. (2006). Regional mapping of phyllic-and argillic-altered rocks in the Zagros magmatic arc, Iran, using Advanced Spaceborne Thermal Emission and Reflection Radiometer (ASTER) data and logical operator algorithms. Geosphere, 2(3), 161-186. 25. Mars, J.C., and Rowan, L.C. (2010). Spectral assessment of new ASTER SWIR surface reflectance data products for spectroscopic mapping of rocks and minerals. Remote Sensing of Environment, 114(9), 2011-2025.

26. Massironi, M., Bertoldi, L., Calafa, P., Visonà, D., Bistacchi, A., Giardino, C., and Schiavo, A. (2008). Interpretation and processing of ASTER data for geological mapping and granitoids detection in the Saghro massif (eastern Anti-Atlas, Morocco). Geosphere, 4(4), 736-759.

27. Mazumdar, S.K., and Chatterjee, S. (1990). A note on the geotectonic status of the Tamar Porapahar fracture zone near the southern edge of the CGGC. Bull. Geol. Min. Metall. Soc. India 56, 12.

28. Ninomiya, Y. (2004, February). Lithologic mapping with multispectral ASTER TIR and SWIR data. Remote Sensing. International Society for Optics and Photonics, 180-190.

29. Ninomiya, Y. (2003). Rock type mapping with indices defined for multispectral thermal infrared ASTER data: case studies. Proceedings of SPIE, 4886, 123-132.

30. Ninomiya, Y., and Bihong, F.U. (2002). Quartz index, carbonate index and $\mathrm{SiO} 2$ content index defined for ASTER TIR data. Journal of The Remote Sensing Society of Japan, 22(1), 50-61.

31. Noori, L., Pour, A.B., Askari, G., Taghipour, N., Pradhan, B., Lee, C.W., and Honarmand, M. (2019). Comparison of Different Algorithms to Map Hydrothermal Alteration Zones Using ASTER Remote Sensing Data for Polymetallic Vein-Type Ore Exploration: Toroud-Chahshirin Magmatic Belt (TCMB), North Iran. Remote Sensing, 11(5), 495. 


\title{
International Advanced Research Journal in Science, Engineering and Technology
}

\author{
Vol. 8, Issue 8, August 2021
}

\section{DOI: 10.17148/IARJSET.2021.8899}

32. Pour, A.B., and Hashim, M. (2012). The application of ASTER remote sensing data to porphyry copper and epithermal gold deposits. Ore geology reviews, 44, 1-9.

33. Pour, B.A., and Hashim, M., (2014). Alteration mineral mapping using ETM+ and hyperion remote sensing data at Bau Gold Field, Sarawak, Malaysia. IOP Conference Series: Earth and Environmental Science 18 (1), 012149.

34. Pour, A.B., Hashim, M., and van Genderen, J. (2013). Detection of hydrothermal alteration zones in a tropical region using satellite remote sensing data: Bau goldfield, Sarawak, Malaysia. Ore Geology Reviews, 54, 181-196.

35. Richards, J.A., and Jia, X. (2006). Multispectral Transformations of Image Data. Remote Sensing Digital Image Analysis: An Introduction, 137-163.

36. Rajendran, S., and Nasir, S. (2017). Characterization of ASTER spectral bands for mapping of alteration zones of Volcanogenic Massive Sulphide (VMS) deposits. Ore Geology Reviews.

37. Rowan, L.C., and Mars, J.C. (2003). Lithologic mapping in the Mountain Pass, California area using Advanced Spaceborne Thermal Emission and Reflection Radiometer (ASTER) data. Remote Sensing of Environment, 84, 350-366.

38. Sabins, F.F. (1999). Remote sensing for mineral exploration. Ore Geology Reviews,14(3-4), 157-183.

39. Saha, A. K. (1994). Crustal Evolution of Singhbhum North Orissa Eastern India. Mem. Geolog. Soc. India.

40. San, B.T., and Suzen, M.L. (2010). Comparison of atmospheric correction techniques for Hyperion data. Int. Arch. Photogramm., Remote Sens. Spat. Inf. Sci, 38(8), 392-397.

41. Sanyal, S., and Sengupta, P. (2012). Metamorphic evolution of the Chotanagpur Granite Gneiss Complex of the East Indian Shield: current status. Geological Society, London, Special Publications, 365(1), 117-145.

42. Tiwari, P.S., Sen, A.K., and Garg, R.D. (2011). Application of DPCA Technique in Khetri Copper Belt, India for Alteration Zones. Asian Journal of Earth Sciences, 4(1), 54.

43. Van der Meer, F.D., Van der Werff, H.M., van Ruitenbeek, F.J., Hecker, C.A., Bakker, W.H., Noomen, M.F., and Woldai, T. (2012). Multi-and hyperspectral geologic remote sensing: A review. International Journal of Applied Earth Observation and Geoinformation, 14(1), $112-128$.

44. Velosky, J.C., Stern, R.J., and Johnson, P.R. (2003). Geological control of massive sulfide mineralization in the Neoproterozoic Wadi Bidah shear zone, southwestern Saudi Arabia, inferences from orbital remote sensing and field studies. Precambrian Research, 123 (2-4), $235-247$.

45. Vicente, L.E., and de Souza Filho, C.R. (2011). Identification of mineral components in tropical soils using reflectance spectroscopy and advanced spaceborne thermal emission and reflection radiometer (ASTER) data. Remote Sensing of Environment, 115(8), $1824-1836$. 